\title{
Bioconversion of apple pomace into a multienzyme bio-feed by two mixed strains of Aspergillus niger in solid state fermentation
}

\author{
Sun Zhong-Tao \\ College of Life Sciences \\ Shandong Agricultural University \\ Tai'an 271018, P. R. China \\ Tel: 865388242908 \\ Fax: 865388249157 \\ E-mail: zhtsun@163.com \\ Tian Lin-Mao \\ College of Life Science and Technology \\ Gansu Agricultural University \\ Lanzhou 730046, P. R. China \\ E-mail: maoaidi2005@sohu.com \\ Liu Cheng \\ College of Life Sciences \\ Shandong Agricultural University \\ Tai'an 271018, P. R. China \\ Tel: 865388242908 \\ Fax: 865388249157 \\ E-mail: lcw@sdau.edu.cn \\ Du Jin-Hua* \\ College of Food Science and Technology \\ Shandong Agricultural University \\ Tai'an 271018, P. R. China \\ Tel.: 865388249157 \\ Fax: 865388249157 \\ E-mail: zhtsun@sdau.edu.cn \\ Website: http://www.sdau.edu.cn
}

Financial support: The Key Technologies R\&D Programme of Shandong province, China (No. 2005GG110902002).

Keywords: apple pomace, Aspergillus niger, multienzyme bio-feed, pectin, solid state fermentation, tannins.

Apple pomace is a wasted resource produced in large quantities and its deposit has caused serious environmental problems, so it is significance to make the full utilization of the residues. The objectives of this work were to produce multienzyme bio-feed, biodegrade the anti-nutritional factors such as pectin and tannins in apple pomace, and obtain the nutritional enrichment of the fermented substrate. The mixture of apple pomace and cottonseed powder $(1: 1, w / w)$, supplemented with $1 \%(\mathrm{w} / \mathrm{w})\left(\mathrm{NH}_{4}\right)_{2} \mathrm{SO}_{4}$ and $0.1 \%$ (w/w) $\mathrm{KH}_{2} \mathrm{PO}_{4}$, was proved to be the optimum medium for the mixed strains of Aspergillus niger $\mathbf{M}_{2}$ and $\mathbf{M}_{3}$ $(2: 1, w / w)$. The activities of pectinase, proteinase and cellulase achieved $21168 \mathrm{u} / \mathrm{g}, 3585 \mathrm{u} / \mathrm{g}$ and 1208u/g, and the biodegradation rates of pectin and tannins reached $99.0 \%$ and $66.1 \%$, respectively, when $0.4 \%(w / w)$ of the test fungiwere inoculated and incubated at $30^{\circ} \mathrm{C}$ for 48 hrs in solid state fermentation. The utilization of apple pomace in the paper can be served as a model for the similar waste recycling.

More than 100 million tons of apple pomace, the solid residues in the process of juice extraction from apples, are produced in China every year. Only 25\%-30\% of the residues are used as fertilizer, fuel, feedstuff or industrial materials, and the other of them are deposited as waste, which results in not only a huge economic loss, but also a series of environmental problems (Joshi and Devender, 2006). Therefore, more and more people have been focusing on the full utilization of apple pomace. Many methods have been adopted to solve this problem, such as to produce pectin, ethanol, lactic acid, citric acid, enzyme and other productions with apple pomace as raw material (Zheng and Shetty, 2000; Shojaosadati and Babaeipour, 2002; Schieber et al. 2003; Joshi and Devender, 2006; Joshi et al. 2006). In fact, these methods can not be put into

*Corresponding author 
application in a large scale due to their faulty manufacturing technique and high production costs.

At present, the most feasible way to make the best of apple pomace is using it to feed animals, but several factors adversely affect its value as a feedstuff. Firstly, the large amount of anti-nutritional factors such as pectin and tannins in the apple pomace affect its nutrition utilization in animal digestion. Secondly, the protein content in apple pomace is very low so that the nutritional levels as well as the commercial value all decrease greatly (Villas-Boas et al. 2003). Thus, it is a key step to biodegrade the antinutritional factors and to improve the nutritional value in apple pomace by some specific microorganisms. Various microorganisms and culture strategies have been tried to improve the nutritional value of apple pomace, including Candida utilis, Aspergillus niger, Aspergillus oryzae, Fusarium moniliforme and Pleurotus ostreatus (Joshi et al. 2000; Shojaosadati and Babaeipour, 2002; Niture and Pant, 2007). However, little has been reported concerning the biodegradation of pectin and tannins, the main antinutritional factors in apple pomace.

Compared with the conventional feedstuff, the advantages of bio-feed lie in not only the high content of protein, but also the various microorganism metabolites produced in the process of fermentation, especially the enzymes interrelated. Apple pomace has been used as the raw material to produce bio-feed with enriched enzymes, such as pectinase, cellulase, xylanase and amylase, while there was no proteinase found in all the reported productions (Zheng and Shetty, 2000; Joshi and Devender, 2006). This suggests that the enzyme compositions of these productions need further improvement as a multienzyme bio-feed.

Moreover, almost all the previous studies have aimed at one of the three aims alone, that is, the production of high activities of enzymes, the increase of protein concentration and the biodegradation of anti-nutritional factors. In this paper, the three aims were achieved at one time by the two mixed strains of Aspergillus niger in solid state fermentation, which has never been reported before.

\section{MATERIALS AND METHODS}

\section{Microorganisms}

Two pectinase and cellulase producing strains, Aspergillus niger $\mathrm{M}_{1}$ and Aspergillus niger $\mathrm{M}_{2}$, and two proteinase producing strains, Aspergillus niger $\mathrm{M}_{3}$ and Aspergillus oryzae $\mathrm{M}_{4}$, were used in the experiment. They were all provided by Xindeli bio-engineering company. The test strains were cultivated in wheat bran medium and incubated at $30^{\circ} \mathrm{C}$ for 5 days respectively. The spores of the 5-day-old culture in wheat bran medium were used as inoculum.

\section{Materials}

The apple pomace and the cottonseed powder, obtained from the Tai'an district of Shandong Province in China, were dried at $60^{\circ} \mathrm{C}$, and then ground in a hammer mill. The powder which passed through the 30 mesh sieve but held by the 50 mesh sieve was collected and stored for the study.

The mixture of apple pomace and cottonseed powder (1:1, $\mathrm{w} / \mathrm{w})$, was humidified and homogenized with distilled water $(1: 1, \mathrm{w} / \mathrm{w})$, acidified to $\mathrm{pH} 4$ with $1 \mathrm{~mol} / \mathrm{l}$ acetic acid, and then used as the basic medium for the fungi.

\section{Cultivation methods}

Fifteen grams of culture medium was put into a $250 \mathrm{ml}$ conical flask sealed with six-layer sterile gauze, sterilized at $121^{\circ} \mathrm{C}$ for $20 \mathrm{~min}$. The spores of the tested strains were weighed and mixed with medium according to pitching rate (weight percentage of spores in the medium), then incubated at $30^{\circ} \mathrm{C}$ for $48 \mathrm{hrs}$. The fermented substrates were dried at $50^{\circ} \mathrm{C}$ for $24 \mathrm{hrs}$ and were subsequently processed into flour for related analyses. Three replications were adopted for each test.

\section{The screen of the optimum combination of the test strains}

To screen the optimum combination from the four test strains, two different strains of them were mixed well at the ratio of $1: 1$, inoculated into the basic medium at the rate of $0.5 \%(\mathrm{~W} / \mathrm{W})$, and incubated at $30^{\circ} \mathrm{C}$ for $48 \mathrm{hrs}$. The fermentation using a single pure strain was adopted as the control. To optimize the ratio of strain $\mathrm{M}_{2}$ to strain $\mathrm{M}_{3}$ in the optimized combination of test strains, the two strains were mixed well at different ratio respectively, inoculated into the basic medium at the rate of $0.5 \%(\mathrm{~W} / \mathrm{W})$, and incubated at $30^{\circ} \mathrm{C}$ for $48 \mathrm{hrs}$.

\section{Optimization of the ratio of apple pomace to cottonseed powder}

The single-factor test was used to determine the optimal ratio of apple pomace to cottonseed powder. Apple pomace and cottonseed powder were mixed well at different ratio from 2:8 to 7:3, and used as culture medium. Strain $\mathrm{M}_{2}$ and strain $\mathrm{M}_{3}(2: 1, \mathrm{w} / \mathrm{w})$ were inoculated into the different culture medium at the rate of $0.5 \%(\mathrm{~W} / \mathrm{W})$ and incubated at $30^{\circ} \mathrm{C}$ for $48 \mathrm{hrs}$. The basic medium was adopted as the control.

\section{The screen of the optimum inorganic nitrogen sources}

Several inorganic salts including $\mathrm{NH}_{4} \mathrm{NO}_{3},\left(\mathrm{NH}_{4}\right)_{2} \mathrm{SO}_{4}$, $\mathrm{NaNO}_{3}$ and $\mathrm{NH}_{4} \mathrm{Cl}$ were adopted to screen the optimum inorganic nitrogen sources for the enzyme production by single-factor test. The mixture of apple pomace and cottonseed powder $(5: 5, \mathrm{w} / \mathrm{w})$ supplemented with $1 \%(\mathrm{w} / \mathrm{w})$ of the inorganic salts above was used as culture medium, and $0.5 \%(\mathrm{~W} / \mathrm{W})$ of the well-mixed spores of the strain $\mathrm{M}_{2}$ and strain $\mathrm{M}_{3}(2: 1, \mathrm{w} / \mathrm{w})$ were used as inoculums. The fermentation was carried out at $30^{\circ} \mathrm{C}$ for $48 \mathrm{hrs}$. The mixture of apple pomace and cottonseed powder $(5: 5, \mathrm{w} / \mathrm{w})$ 
supplemented without inorganic salts was adopted as the control.

\section{Orthogonal experiment design}

A four-factor-three-level orthogonal experiment was adopted to optimize the level of the initial moisture, substrate load, $\left(\mathrm{NH}_{4}\right)_{2} \mathrm{SO}_{4}$ and $\mathrm{KH}_{2} \mathrm{PO}_{4}$. The levels of the four factors are shown in Table 1 . The optimized ratio of apple pomace and cottonseed powder $(5: 5, \mathrm{w} / \mathrm{w})$ was adopted in the test. The well-mixed spores of the strain $\mathrm{M}_{2}$ and strain $\mathrm{M}_{3}(2: 1, \mathrm{w} / \mathrm{w})$ were used as inoculums, and the inoculum level was $0.5 \%(\mathrm{~W} / \mathrm{W})$. The fermentation was carried out at $30^{\circ} \mathrm{C}$ for $48 \mathrm{hrs}$. The orthogonal experiment was done twice and all measurements were carried out in triplicate. (Table 1)

\section{Optimization of inoculum level, incubation temperature and initial $\mathrm{pH}$}

The single-factor experiment was adopted to optimize the important fermentation parameters including inoculum level, incubation temperature and initial $\mathrm{pH}$. Strains $\mathrm{M}_{2}$ and $\mathrm{M}_{3}(2: 1, \mathrm{w} / \mathrm{w})$ and the optimized medium obtained above were adopted in this test. To optimize the inoculum level, various inoculum levels from $0.2 \%(\mathrm{w} / \mathrm{w})$ to $0.6 \%(\mathrm{w} / \mathrm{w})$ were used to evaluate their effects on the production of enzymes, while the incubation temperature and initial $\mathrm{pH}$ were fixed at $30^{\circ} \mathrm{C}$ and $\mathrm{pH} 4.0$. To determine the effect of incubation temperature on the enzyme production, the fermentation was carried out at various temperatures from $21^{\circ} \mathrm{C}$ to $33^{\circ} \mathrm{C}$ for $48 \mathrm{hrs}$, while the inoculum level was fixed at its optimized level $(0.4 \%, \mathrm{w} / \mathrm{w})$ and the initial $\mathrm{pH}$ was fixed at $\mathrm{pH}$ 4.0. To optimize the initial $\mathrm{pH}$, the solid medium with different initial $\mathrm{pH}$ levels were employed from $\mathrm{pH} 3$ to $\mathrm{pH} \mathrm{7,adjusted} \mathrm{with} 1 \mathrm{~mol} / \mathrm{l}$ acetic acid or 1 $\mathrm{mol} / \mathrm{l} \mathrm{NaOH}$, while the inoculum level and incubation temperature were fixed at their optimized levels $(0.4 \%$, $\left.\mathrm{w} / \mathrm{w} ; 30^{\circ} \mathrm{C}\right)$.

\section{Effect of incubation time on the enzyme production and biodegradation of anti-nutritional factors}

The fermentation was performed with all the parameters kept at their optimized level. Thirty conical flasks were adopted in this experiment, and the fermentation of three flasks was terminated every $12 \mathrm{hrs}$. The fermented substrate was mixed well, dried in an oven at $50^{\circ} \mathrm{C}$ for $24 \mathrm{hrs}$, and used as the samples for related analyses.

\section{Assay of enzyme activities}

One gram of the fermented substrate was ground with 0.1

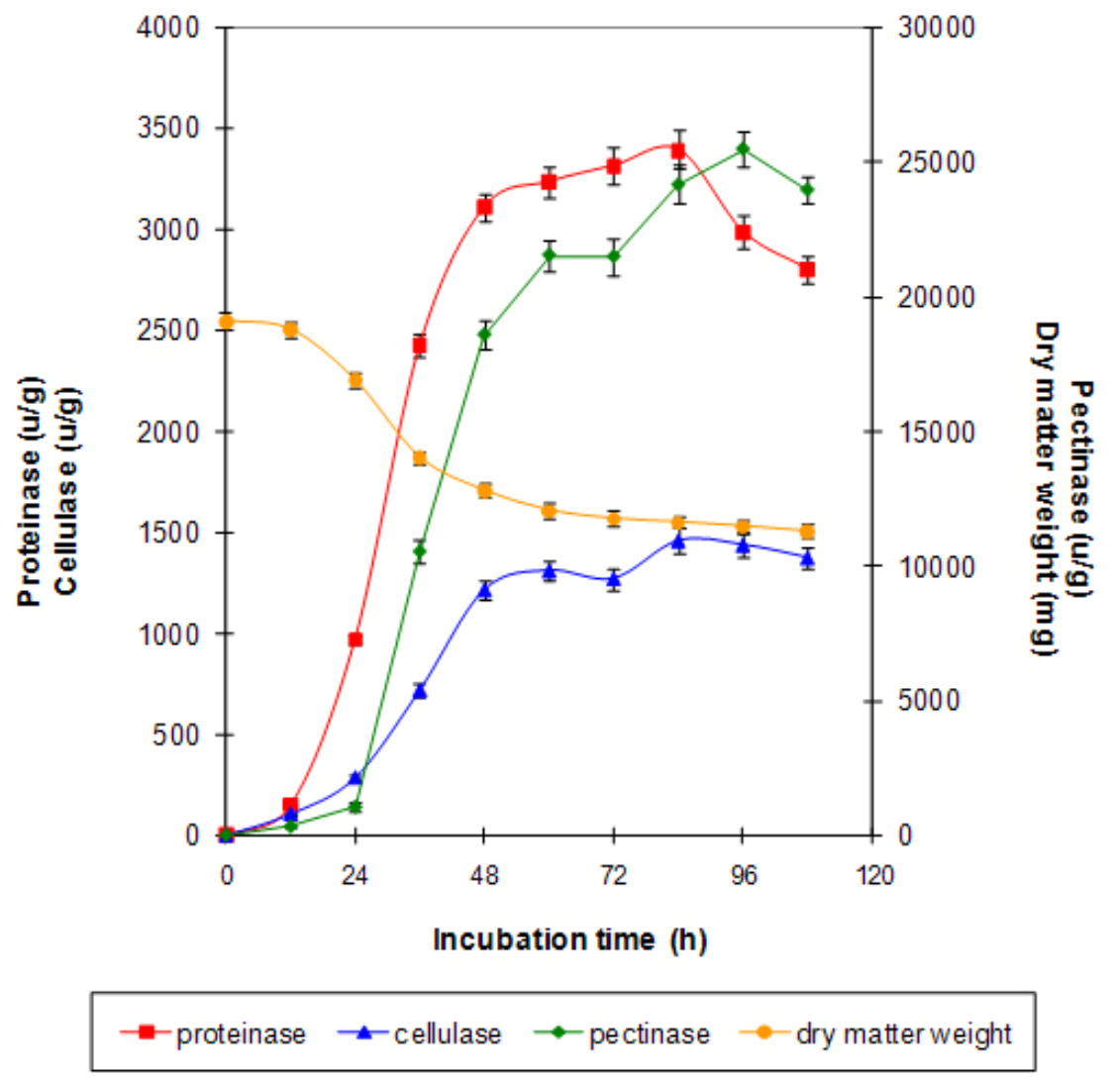

Figure 1. Effect of incubation time on the enzyme production and dry matter weight loss. 
$\mathrm{mol} / \mathrm{l}$ acetic acid buffer $(\mathrm{pH}$ 5.0) to extract pectinase and cellulase, or ground with $0.05 \mathrm{~mol} / \mathrm{l}$ lactic acid buffer $(\mathrm{pH}$ $3.0)$ to extract acidic proteinase. Solutions $(10 \mathrm{mg} / \mathrm{ml})$ of pectin and sodium carboxymethyl cellulose were used as the substrates to determine the enzyme activities of pectinase (Wang et al. 2006) and cellulase (König et al. 2002), respectively. One milliliter of enzyme extract was mixed with $1 \mathrm{ml}$ of the substrate, and then incubated at $40^{\circ} \mathrm{C}$ for $20 \mathrm{~min}$. The enzymatic reaction was terminated by adding $1.5 \mathrm{ml}$ of DNS reagent (Colombatto et al. 2003), and then diluted to $25 \mathrm{ml}$. The absorbance was obtained at $540 \mathrm{~nm}$ by an Ultrospec 4300 pro UV-Visible Spectrophotometer (Pharmacia), while the reaction solution containing the boiled enzyme-extract was used as the control. One unit of the activity of pectinase or cellulase was defined as the amount of enzymes required to release 1 $\mathrm{mg}$ galacturonic acid or glucose in $1 \mathrm{hr}$. The acidic proteinase activity was assayed by measuring its ability to hydrolyze casein (Aoyama et al. 2000). One unit of acidic proteinase activity was defined as the amount of enzyme required to release $1 \mu \mathrm{g}$ tyrosine in $1 \mathrm{~min}$.

\section{Determination of anti-nutritional factors, protein and amino acids}

The pectin was determined by the weight method (Wang and Zhang, 1999). The tannins were determined by spectrophotometric method (Chemesova and Chizhikov, 2004). The free gossypol was determined by the official method of the American Oil Chemists Society (AOCS, 1989). The crude protein and the pure protein were mensurated with Kjeldahl method (AOAC, 1999, method 988.05). The amino acid assay was based on the AOAC (1999) method, number 994.12.

\section{Statistical analysis}

In the experiments, all treatments were run in triplicate and all experiments were repeated at least twice. Data from each treatment were subjected to SPSS for ANOVA, and LSD test was used to determine significant differences $(\mathrm{p}<$ 0.05 ) among the treatments.

\section{RESULTS}

\section{Effect of the test strains on the enzyme production}

The data in Table 2 showed that the enzyme activities varied with the different types and the different proportions of the test strains. The enzyme composition of the fermented substrate was not satisfied when single microorganism was adopted, because the strain $\mathrm{M}_{1}$ and $\mathrm{M}_{2}$, pectinase and cellulase-producing fungi, could not produce high activities of proteinase, and the strain $\mathrm{M}_{3}$ and $\mathrm{M}_{4}$, proteinase-producing fungi, could not produce high activities of pectinase and cellulase. But when the two different strains were adopted together, the activities of all the three enzymes were very high. The maximum value of total activities from the three enzymes were obtained when strain $\mathrm{M}_{2}$ and strain $\mathrm{M}_{3}$ were mixed at the ratio of 2:1 (W/W) (Table 2).

\section{Effect of the ratio of apple pomace to cottonseed powder on the enzyme production}

Cottonseed powder was selected as the nitrogen source because of its high protein concentration and low price. The results were shown in Table 3. The ratio of apple pomace to cottonseed powder had an important influence on the enzyme production. When the ratio was $3: 7(\mathrm{w} / \mathrm{w})$, the proteinase activity reached the maximum; while when the ratio was $5: 5(\mathrm{w} / \mathrm{w})$, the activities of pectinase and cellulase approached the maximum. In a comprehensive survey, we adopted the ratio of 5:5 (w/w) as the optimum ratio of apple pomace to cottonseed powder, which was used throughout the following tests. Coincidentally, the optimized ratio (5:5, $\mathrm{w} / \mathrm{w})$ here was the exact ratio adopted in the basic medium (Table 3).

\section{Effects of various inorganic nitrogen source on the enzyme production}

As was shown in Table 4, the enzyme production was higher than the control when the substrate was supplemented with any kind of inorganic nitrogen source. The highest enzymes production was obtained when $1 \%$ (w/w) of $\left(\mathrm{NH}_{4}\right)_{2} \mathrm{SO}_{4}$ was added to the substrate (Table 4).

\section{Analysis of enzyme activities in orthogonal experiment}

Besides the initial moisture, substrate load and $\left(\mathrm{NH}_{4}\right)_{2} \mathrm{SO}_{4}$, the level of $\mathrm{K}_{2} \mathrm{HPO}_{4}$ wasalso optimized in the orthogonal experiment, because both phosphorus and potassium are the most important inorganic elements for the growth and metabolism of microorganism, and it was reported that $\mathrm{K}_{2} \mathrm{HPO}_{4}$ can improve the production of hydrolytic enzymes such as proteinase, pectinase and cellulase (Wang et al. 2006). The results of the orthogonal experiment were shown in Table 5. The activities of pectinase, proteinase and cellulase varied considerably within the tested conditions in the range of 11713-21168 u/g, 2334-3761 $\mathrm{u} / \mathrm{g}, 919-1208 \mathrm{u} / \mathrm{g}$, respectively, which indicated that these parameters above strongly affected the production of enzymes by the two mixed strains of $A$. niger in solid state fermentation.

The Fisher's test for ANOVA was used to identify the factors with statistically significant effects. The F-values of factors $\mathrm{A}$ and $\mathrm{B}$ for the three enzymes were higher than $\mathrm{F}_{0.01}\left(\mathrm{~F}_{0.01}=8.02\right)$, which indicated that both initial moisture level and substrate load had significant influence on all the three enzymes at the $1 \%$ level of significance. The $\mathrm{F}$-value of factor $\mathrm{C}$ for pectinase was higher than $\mathrm{F}_{0.05}$ $\left(\mathrm{F}_{0.05}=4.26\right)$, while the $\mathrm{F}$-value for proteinase and cellulase was lower than $\mathrm{F}_{0.05}$, which suggested that $\left(\mathrm{NH}_{4}\right)_{2} \mathrm{SO}_{4}$ had a significant influence on pectinase, but had no significant 
influence on proteinase and cellulase at the 5\% level of significance. The $\mathrm{F}$-value of factor $\mathrm{D}$ for proteinase was higher than $\mathrm{F}_{0.01}$ and that for cellulase was higher than $\mathrm{F}_{0.05}$, indicated that $\mathrm{KH}_{2} \mathrm{PO}_{4}$ had a significant influence on proteinase at the $1 \%$ level of significance and a significant influence on cellulase at the $5 \%$ level of significance. However, the $\mathrm{F}$-value of factor $\mathrm{D}$ for pectinase was lower than $\mathrm{F}_{0.05}$, showing that $\mathrm{KH}_{2} \mathrm{PO}_{4}$ had no significant influence on pectinase at the $5 \%$ level of significance. The statistical and mathematical analysis of ANOVA above was consistent with the results of range analysis, in which the higher the R-value, the more significant is the corresponding factor.

The range analysis was adopted to determine the optimum levels of the four factors. The level with the maximum Kvalue was the optimum level. For all the three enzymes, the second levels of factor A and factor B were the optimum levels. The optimum levels of factor $\mathrm{C}$ were the first level for pectinase and the second level for proteinase and cellulase respectively. As for the factor D, the first level was the optimum level for proteinase, and the second level was the best level for pectinase and cellulase. In a comprehensive survey, we adopted $\mathrm{C} 1$, the best level of factor $\mathrm{C}$ for pectinase, and D1, the best level of factor $\mathrm{D}$ for proteinase, as the best level for the three enzymes. In conclusion, the optimum combination of the four factors was A2 B2 C1 D1, which suggested that the optimum levels of the initial moisture content, substrate load, $\left(\mathrm{NH}_{4}\right)_{2} \mathrm{SO}_{4}$ and $\mathrm{K}_{2} \mathrm{HPO}_{4}$ were $55 \%(\mathrm{w} / \mathrm{w}), 15 \mathrm{~g}, 1 \%(\mathrm{w} / \mathrm{w})$ and $0.1 \%(\mathrm{w} / \mathrm{w})$ respectively (Table 5$)$.

\section{Effect of inoculum level, incubation temperature and initial $\mathrm{pH}$ on the enzyme production}

The inoculum level, incubation temperature and initial $\mathrm{pH}$ value of the culture medium were the most important conditions affecting the solid-state fermentation (Krishna, 2005). As was shown in Table 6, the activities of pectinase, proteinase and cellulase varied along with the inoculum level, and reached their maximum at the inoculum level of $0.4 \%(\mathrm{~W} / \mathrm{W})$. Higher inoculum level did not benefit the enzyme activities, and on the contrary, it led to the higher temperature of the culture. However, if the inoculum size was too less, the strains grew slowly and the fermentation duration would be prolonged. Data in Table 6 also revealed that the activities of the three enzymes achieved their maximum at different temperature and initial $\mathrm{pH}$. The optimum temperature was $27^{\circ} \mathrm{C}$ for proteinase, but $30^{\circ} \mathrm{C}$ for pectinase and cellulase. The optimum initial $\mathrm{pH}$ value was $\mathrm{pH} 4.0$ for pectinase, but $\mathrm{pH} 5.0$ for proteinase and cellulase. In a comprehensive survey, we took $0.4 \%$ $(\mathrm{W} / \mathrm{W}), 30^{\circ} \mathrm{C}$ and $\mathrm{pH} 4.0$ as the optimum inoculum level, incubation temperature and initial $\mathrm{pH}$ value, and these

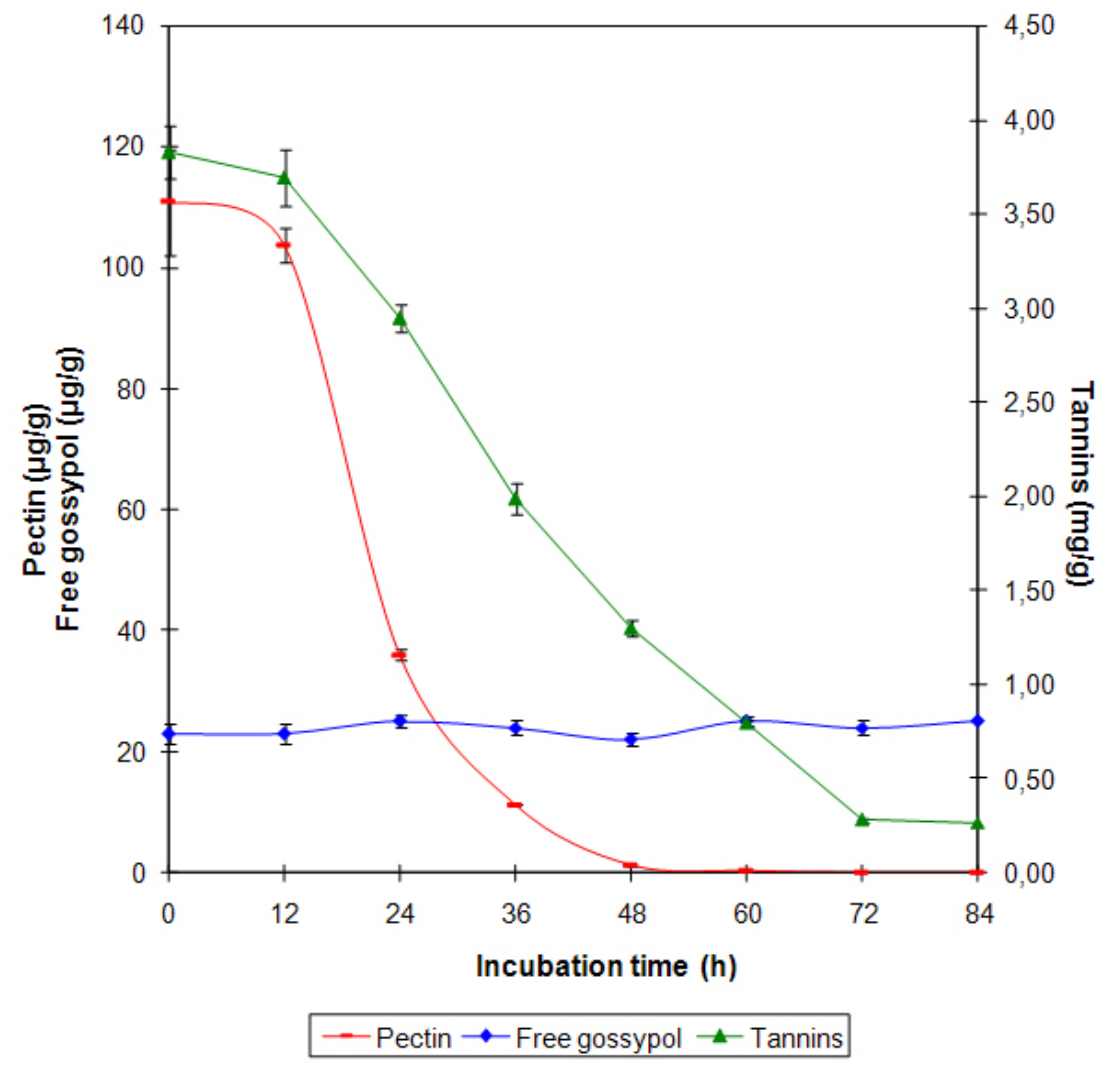

Figure 2. Effect of incubation time on the residual levels of pectin, tannins and free gossypol. 
optimized conditions were adopted throughout the following experiments (Table 6).

\section{Effect of incubation time on the enzyme production and dry matter weight loss}

Direct determination of biomass in solid medium is very difficult because it is impossible to separate the organism from the substrate. Terebiznik and Pilosof (1999) found that dry matter weight loss was highly correlated with the biomass, and the biomass in solid-state fermentation system can be estimated by determining the dry matter weight loss (Weng and Sun, 2006). In this experiment, the dry matter weight loss of the substrate, together with the activities of the three enzymes, was measured at different fermentation time. The results were given in Figure 1. At the beginning (0-24 hrs), the loss of dry matter weight was in a micro scale and only a small quantity of proteinase and cellulase was produced. At the same time, no pectinase occurred. During the fermentation period of 24-48 hrs, the fungi grew fast, resulting in a rapid decrease of dry matter weight and the obvious increase of enzyme activities. This result was consistent with the previous reports (Wang et al. 2006). During the next fermentation stage (48-84 hrs), the growth of the fungislowed down, so did the changing in the dry matter weight and the enzyme activities. Since a great amount of spores would be produced after $48 \mathrm{hrs}$ of fermentation, which turned the color of the substrate into black and did harm to animal, the fermentation should be terminated at $48 \mathrm{hrs}$ of the fermentation (Figure 1).

\section{Biodegradation of anti-nutritional factors}

Pectin and tannins were the main anti-nutritional factors in apple pomace. Figure 2 revealed that the biodegradation of pectin and tannins by the test fungidepended on their growth state. At $12 \mathrm{hrs}$ of fermentation, the biodegradation rate of pectin and tannins was only $6.4 \%$ and $2.3 \%$ respectively. With the fungi growing quickly, pectin and tannins were biodegraded promptly during $12-48 \mathrm{hrs}$ of the fermentation, and the biodegradation rates were as high as $99.0 \%$ and $66.1 \%$ at $48 \mathrm{hrs}$, respectively.

Data in Figure 2 also indicated that the gossypol, a toxin in cottonseed powder, could not be biodegraded by the test fungi. The initial content of free gossypol in the cottonseed powder is as high as $382 \mu \mathrm{g} / \mathrm{g}$, but after the treatment of autoclaved, most of the free gossypol was turned into the bound state, which did no harm to animals (Robinson et al. 2001); and the residual free gossypol level in the fermented substrate was $23 \mu \mathrm{g} / \mathrm{g}$, far below $100 \mu \mathrm{g} / \mathrm{g}$, the maximum level of free gossypol for animal feed standard prescribed in China. Therefore, the cottonseed powder is a safe nitrogen source used to produce bio-feed after the autoclaved treatment even if the free gossypol could not be biodegraded by the test fungi (Figure 2).
Effect of fermentation on the protein and amino acid concentration in the substrate

Table 7 showed that the fermentation improved the nutritional levels of the substrate greatly. The contents of crude protein and pure protein were improved markedly ( $\mathrm{P}$ $<0.05$ ), approaching $40.8 \%$ and $34.7 \%$, respectively. The total amino acids as well as the essential amino acids were also increased remarkably $(\mathrm{P}<0.05)$, reaching $46.8 \%$ and $71.7 \%$, respectively. As for the levels of methionine, lysine and threonine, they were all enhanced greatly $(\mathrm{P}<0.05)$, achieving $83.6 \%, 51.3 \%$ and $98.7 \%$, respectively (Table 7 ).

\section{DISCUSSION}

In this paper, a solid state fermentation technology by two mixed strains of $A$. niger was adopted to produce a multienzyme bio-feed from apple pomace due to its several advantages. First, solid state fermentation owns the characteristics such as the low capital costs for equipments, high volumetric productivity and decreased operational expenditures (Krishna, 2005; Araya et al. 2007). Second, compared with the conventional fermentation using a single pure culture, the mixed culture fermentation obtains higher product yield and growth rate, utilizes cheap and impure substrates, overcomes nutritional limitations in poor agricultural residues, and strengthens the protection of the culture against contamination (Yang et al. 2004; Oboh, 2006). As shown in Table 2, the strain $M_{2}$ could secrete high activities of cellulase and pectinase; the strain $\mathrm{M}_{3}$ could secrete high activities of proteinase; the two strains could benefit from each other and accelerate enzyme activities mutually in the mixed culture fermentation.

The enzyme composition was the most important factor which affected the value of the fermented substrate as a multienzyme bio-feed. In fact, there was almost no proteinase in all the reported bio-feed produced from apple pomace (Joshi et al. 2000; Shojaosadati and Babaeipour, 2002; Niture and Pant, 2007). This was caused by two reasons. Firstly, since the lignin and cellulose content in apple pomace were very high, microorganisms producing xylanase and cellulase were often adopted by researchers, while these microorganisms often could not produce high activities of proteinase. Secondly, $\left(\mathrm{NH}_{4}\right)_{2} \mathrm{SO}_{4}$ and other inorganic salts, or supplemented with a little of wheat bran, were often adopted as nitrogen source, which could not induce the secretion of proteinase from microorganisms in larger quantity. In this paper, in order to overcome the two obstacles above, a proteinase-producing strain in addition to a cellulase-producing strain was adopted and a larger quantity of cottonseed powder was used as the nitrogen source. Therefore, the proteinase was produced in high activities in the solid state fermentation---this was also a highlight of our work. Moreover, three different enzymes were produced at one time in the process of fermentation and needed not to be combined any more when used as feedstuff, so the production cost was saved further. 
Given the low profit and the high raw material cost in feed industry, the selection of nitrogen source was always carried out in deep consideration. $\left(\mathrm{NH}_{4}\right)_{2} \mathrm{SO}_{4}$ and other inorganic salts were often adopted as nitrogen source in the first place, but the quality of bio-feed will be affected by the residual $\mathrm{NH}_{4}^{+}$when too much $\left(\mathrm{NH}_{4}\right)_{2} \mathrm{SO}_{4}$ was added. Thus, the increase of protein content andthe bioconversion ability of microorganisms were all limited by the dosage of $\left(\mathrm{NH}_{4}\right)_{2} \mathrm{SO}_{4}$. Moreover, the enzyme composition was not appropriate when $\left(\mathrm{NH}_{4}\right)_{2} \mathrm{SO}_{4}$ was used as the main nitrogen source as mentioned above. In the paper, these problems were all solved by adopting a larger quantity of cottonseed powder as the main nitrogen source, besides a little $\left(\mathrm{NH}_{4}\right)_{2} \mathrm{SO}_{4}$, which was used as the start-up nitrogen source. Cottonseed powder, which is produced in large quantities every year in China, is one of the cheapest agricultural residues with high protein content. As a major protein resource, it contains free gossypol which would cause negative effects on animals. Therefore, only a little of cottonseed powder is used as feedstuff, and most of it is simply added to soil as a fertilizer, resulting in a huge economic waste (Robinson et al. 2001). Thus, the full utilization of cottonseed powder is another problem needed to be solved in China. In this paper, the free gossypol was detoxified during the process of autoclave treatment and the cottonseed powder became a safe protein resource. The two wasted resource, apple pomace and cottonseed powder, all found their full utilization in the paper, and this was another highlight of our work.

Besides the low content of protein, the large amount of pectin and tannins limited the application of apple pomace as feedstuff. Pectin and tannins might reduce the feed ingestion, the weight gain and the empty carcass weight percentage of animals when apple pomace was used as feedstuff (Getachew et al. 2001; Drochner et al. 2004). In this paper, pectin and tannins were biodegraded by the two strains of A. niger, and their concentration decreased by $99.0 \%$ and $66.1 \%$, respectively, much higher than that in other related reports (Villas-Boas et al. 2003; Ruiz-Aguilar, et al. 2004). At the same time, the concentration of protein and amino acids of the fermented substrate increased significantly. All these suggested that the fermented apple pomace carried not only lower content of anti-nutritional factors, but also higher nutritional values.

In conclusion, the solid-state fermentation of apple pomace by the two mixed strains of $A$. niger was an efficient biological treatment and it reached our objective, that is, to produce multienzyme bio-feed, to biodegrade pectin and tannins, and to improve nutritional level of the fermented substrate. The utilization of apple pomace in the paper can be served as a model for the fruit-processing wastes such as cranberry pomace, strawberry pomace.

\section{ACKNOWLEDGMENTS}

The authors wish to express their gratitude to Ph.D. Wang Bing for skillful technical assistance.

\section{REFERENCES}

AOCS. Free and total gossypol methods. In: Official and Tentative Methods of the AOCS, $4^{\text {th }}$ ed. American Oil Chemists' Society, Chicago, 1989.

AOYAMA, M.; YASUDA, M.; NAKACHI, K.; KOBAMOTO, N.; OKU, H. and KATO, F. Soybean-milkcoagulating activity of Bacillus pumilus derives from a serine proteinase. Applied Microbiology and Biotechnology, April 2000, vol. 53, no. 4, p. 390-395.

ARAYA, M. Macarena; ARRIETA, Juan J.; PÉREZCORREA, J. Ricardo; BIEGLER, Lorenz T. and JORQUERA, Héctor. Fast and reliable calibration of solid substrate fermentation kinetic models using advanced nonlinear programming techniques. Electronic Journal of Biotechnology [online], 15 January 2007, vol. 10, no. 1.

Association of Official Analytical Chemists (AOAC). Official Methods of Analysis, $16^{\text {th }}$ ed. 1999, Washington, DC, USA. 1200 p. ISBN 978-0935584547.

CHEMESOVA, I.I. and CHIZHIKOV, D.V. Determination of tannin content in rhizomes of Comarum palustre L. and its tincture by spectrophotometric method. Rastitel'nye Resursy, 2004, vol. 40, no. 3, p. 122-130.

COLOMBATTO, D.; MOULD, F.L.; BHATT, M.K.; MORGAVI, D.P.; BEAUCHEMIN, K.A. and OWEN, E. Influence of fibrolytic enzymes on the hydrolysis and fermentation of pure cellulose and xylan by mixed ruminal microorganisms in vitro. Journal of Animal Science, April 2003, vol. 81 , no. 4, p. 1040-1050.

DROCHNER, W.; KERLER, A. and ZACHARIAS, B. Pectin in pig nutrition, a comparative review. Journal of Animal Physiology and Animal Nutrition, December 2004, vol. 88 , no. 11-12, p. 367-380.

GETACHEW, G.; MAKKAR, H.P.S. and BECKER, K. Method of polyethylene glycol application to tanninscontaining browses to improve microbial fermentation and efficiency of microbial protein synthesize from tannincontaining browses. Animal Feed Science and Technology, July 2001, vol. 92, no. 1, p. 51-57.

JOSHI, V.K.; GUPTA, K.; DEVRAJAN, A.; LAL, B.B. and ARYA, S.P. Production and evaluation of fermented apple pomace in the feed of broilers. Journal of Food Science and Technology, 2000, vol. 37, no. 6, p. 609-612.

JOSHI, V.K. and DEVENDER, A. Solid state fermentation of apple pomace for the production of value added products. Natural Product Radiance, July- August 2006, vol. 5, no. 4, p. 289-296.

JOSHI, V.K.; MUKESH, P. and RANA, N.S. Pectin esterase production from apple pomace in solid-state and submerged fermentations. (Special issue: Food enzymes 
and additives. Part 1: Enzymes and organic acids for food application). Food Technology and Biotechnology, AprilJune 2006, vol. 44, no. 2, p. 253-256.

KÖNIG, J.; GRASSER, R.; PIKOR, H. and VOGEL, K. Determination of xylanase, $\beta$-glucanase, and cellulase activity. Analytical and Bioanalytical Chemistry, September 2002, vol. 374, no. 1, p. 80-87.

KRISHNA, C. Solid-state fermentation systems - an overview. Critical Reviews Biotechnology, January 2005, vol. 25 , no. 1-2, p. 1-30.

NITURE, S. and PANT, A. Production of cell-wall degrading enzymes by a $\mathrm{pH}$ tolerant estuarine isolate Fusarium moniliforme NCIM1276 in different culture conditions. World Journal of Microbiology and Biotechnology, August 2007, vol. 23, no. 8, p. 1169-1177.

$\mathrm{OBOH}, \mathrm{G}$. Nutrient enrichment of cassava peels using a mixed culture of Saccharomyces cerevisae and Lactobacillus spp solid media fermentation techniques. Electronic Journal of Biotechnology [online], 15 January 2006, vol. 9, no. 1.

ROBINSON, P.H.; GETACHEW, G.; DEPETERS, E.J. and CALHOUN, M.C. Influence of variety and storage for up to 22 days on nutrient composition and gossypol level of Pima cottonseed (Gossypium spp). Animal Feed Science and Technology, June 2001, vol. 91, no. 3, p. 149-156.

RUIZ-AGUILAR, G.M.L.; RIOS-LEAL, E.; TOMASINICAMPOCOSIO, A.; VELOZ-RODRIGUEZ, R.; BARAJAS-ACEVES, M. and RODRIGUEZ-VAZQUEZ, R. Effect of Culture Parameters on the Degradation of Hydrolyzable Tannin Extracted from Cascalote by Aspergillus niger. Bulletin of Environmental Contamination and Toxicology, January 2004, vol. 73, no. 1, p. 45-52.

SCHIEBER, A.; HILT, P.; STREKER, P.; ENDRESS, H.U.; RENTSCHLER, C. and CARLE, R. A new process for the combined recovery of pectin and phenolic compounds from apple pomace. Innovative Food Science and Emerging Technologies, March 2003, vol. 4, no. 1, p. 99-107.

SHOJAOSADATI, S.A. and BABAEIPOUR, V. Citric acid production from apple pomace in multi-layer packed bed solid-state bioreactor. Process Biochemistry, March 2002, vol. 37 , no. 8, p. 909-914.

TEREBIZNIK, M.R. and PILOSOF, A.M.R. Biomass estimation in solid state fermentation by modeling dry matter weight loss. Biotechnology Techniques, March 1999, vol. 13 , no. 3, p. 215-219.

VILLAS-BOAS, S.G.; ESPOSITO, E and MATOS DE MENDONÇA, M. Bioconversion of apple pomace into a nutritionally enriched substrate by Candida utilis and
Pleurotus ostreatus. World Journal of Microbiology and Biotechnology, July 2003, vol. 19, no. 5, p. 461-467.

WANG, X.J.; BAI, J.G. and LIANG, Y.X. Optimization of multienzyme production by two mixed strains in solid-state fermentation. Applied Microbiology and Biotechnology, December 2006, vol. 73, no. 3, p. 533-540.

WANG, Xing-Ping and ZHANG, Wen-Ying. Study on the determination and utilization of the pectin in haw. Quarterly of Forest By-Product and Speciality in China, November 1999, vol. 9, no. 4, p. 13-14.

WENG, Xiao-Yan and SUN, Jian-Yi. Kinetics of biodegradation of free gossypol by Candida tropicalis in solid-state fermentation. Biochemical Engineering Journal. December 2006, vol. 32, no. 3, p. 226-232.

YANG, Y.H.; WANG, B.C.; WANG, Q.H.; XIANG, L.J. and DUAN, C.R. Research on solid-state fermentation on rice chaff with a microbial consortium. Colloids and Surfaces B: Biointerfaces, March 2004, vol. 34, no. 1, p. 16.

ZHENG, Zuo-Xing and SHETTY Kalidas. Solid state production of polygalacturonase by Lentinus edodes using fruit processing wastes. Process Biochemistry, March 2000, vol. 35 , no. 8, p. 825-830. 


\section{APPENDIX}

\section{TABLES}

Table 1. Factors and levels of orthogonal test.

\begin{tabular}{|c|c|c|c|c|}
\hline \multirow[b]{2}{*}{ Levels } & \multicolumn{4}{|c|}{ Factors } \\
\hline & $\begin{array}{c}A \\
\mathrm{H}_{2} \mathrm{O} \\
(\%, w / w)\end{array}$ & $\begin{array}{c}\text { B } \\
\text { Load } \\
\text { (g, dry weight) }\end{array}$ & $\begin{array}{c}\mathrm{C} \\
\left(\mathrm{NH}_{4}\right)_{2} \mathrm{SO}_{4} \\
(\%, \mathrm{w} / \mathrm{w})\end{array}$ & $\begin{array}{c}\mathrm{D} \\
\mathrm{KH}_{2} \mathrm{PO}_{4} \\
(\%, \mathrm{w} / \mathrm{w})\end{array}$ \\
\hline 1 & 50 & 10 & 1.0 & 0.1 \\
\hline 2 & 55 & 15 & 1.5 & 0.2 \\
\hline 3 & 60 & 20 & 2.0 & 0.3 \\
\hline
\end{tabular}

Table 2. Effect of the types and proportions of the test strains on the enzyme production.

\begin{tabular}{|c|c|c|c|c|}
\hline \multicolumn{2}{|c|}{ Microorganism } & \multirow{2}{*}{$\begin{array}{l}\text { Pectinase (u/g) } \\
15064 \pm 424^{\mathrm{a}}\end{array}$} & \multirow{2}{*}{$\begin{array}{l}\text { Proteinase (u/g) } \\
\qquad 567 \pm 20^{\mathrm{a}}\end{array}$} & \multirow{2}{*}{$\begin{array}{c}\text { Cellulase (u/g) } \\
\qquad 1495 \pm 62^{\mathrm{a}}\end{array}$} \\
\hline \multirow{4}{*}{ Single strain } & $\mathrm{M}_{1}$ & & & \\
\hline & $\mathrm{M}_{2}$ & $19265 \pm 505^{b}$ & $427 \pm 19^{a}$ & $1174 \pm 51^{b}$ \\
\hline & $M_{3}$ & $1521 \pm 42^{c}$ & $3681 \pm 109^{b}$ & $264 \pm 12^{c}$ \\
\hline & $\mathrm{M}_{4}$ & $2704 \pm 111^{d}$ & $3415 \pm 139^{c}$ & $725 \pm 34^{d}$ \\
\hline \multirow{4}{*}{$\begin{array}{l}\text { Mixed strains } \\
(1: 1, w / w)\end{array}$} & $\mathrm{M}_{1}: \mathrm{M}_{3}$ & $14620 \pm 365^{a}$ & $3357 \pm 131^{a}$ & $1007 \pm 51^{a}$ \\
\hline & $\mathrm{M}_{1}: \mathrm{M}_{4}$ & $15391 \pm 630^{\mathrm{a}}$ & $2783 \pm 95^{b}$ & $1055 \pm 56^{a}$ \\
\hline & $\mathrm{M}_{2}: \mathrm{M}_{3}$ & $17864 \pm 530^{b}$ & $3274 \pm 123^{\mathrm{ac}}$ & $1156 \pm 45^{b}$ \\
\hline & $\mathrm{M}_{2}: \mathrm{M}_{4}$ & $14572 \pm 462^{\mathrm{a}}$ & $3075 \pm 138^{c}$ & $975 \pm 52^{\mathrm{a}}$ \\
\hline \multirow{4}{*}{$\begin{array}{l}M_{2}: M_{3} \\
(w / w)\end{array}$} & $1: 2$ & $16267 \pm 375^{a}$ & $3329.27 \pm 182^{a}$ & $987 \pm 42^{a}$ \\
\hline & $1: 1$ & $17364 \pm 562^{\mathrm{bc}}$ & $3274 \pm 117^{a b}$ & $1056 \pm 50^{a}$ \\
\hline & $2: 1$ & $18693 \pm 603^{d}$ & $3016 \pm 138^{b c}$ & $1173 \pm 43^{b}$ \\
\hline & $3: 1$ & $18064 \pm 580^{c d}$ & $2774 \pm 118^{c}$ & $1013 \pm 55^{a}$ \\
\hline
\end{tabular}

Each value represents the mean \pm standard error; with no common superscript letter in a column for a group of treatments are significantly different at $p<0.05$. 
Table 3. Effect of the ratio of apple pomace to cottonseed powder on the enzyme production.

\begin{tabular}{|c|c|c|c|}
\hline Ratio & Pectinase activity (u/g) & Proteinase activity (u/g) & Cellulase activity (u/g) \\
\hline $2: 8$ & $15357 \pm 482^{\mathrm{a}}$ & $2959 \pm 108^{\mathrm{a}}$ & $755 \pm 30^{\mathrm{a}}$ \\
\hline $3: 7$ & $15881 \pm 346^{\mathrm{ab}}$ & $4831 \pm 190^{\mathrm{b}} \pm 41^{\mathrm{b}}$ & $998 \pm 37^{\mathrm{b}}$ \\
\hline $4: 6$ & $16564 \pm 528^{\mathrm{b}}$ & $4499 \pm 162^{\mathrm{c}}$ & $1091 \pm 42^{\mathrm{c}}$ \\
\hline $\begin{array}{c}5: 5(1: 1) \\
(\text { Control) }\end{array}$ & $18372 \pm 467^{\mathrm{c}}$ & $3323 \pm 105^{\mathrm{d}}$ & $975 \pm 35^{\mathrm{b}}$ \\
\hline $6: 4$ & $16047 \pm 336^{\mathrm{ab}}$ & $2412 \pm 95^{\mathrm{e}}$ & $614 \pm 26^{\mathrm{d}}$ \\
\hline $7: 3$ & $12418 \pm 308^{\mathrm{d}}$ & $1601 \pm 79^{\mathrm{f}}$ & 69 \\
\hline
\end{tabular}

The basic medium (apple pomace/cottonseed powder, 1/1) was adopted as the control. Each value represents the mean \pm standard error; with no common superscript letter in a column for a group of substrates are significantly different at $p<0.05$.

Table 4. Effects of various nitrogen sources on the enzyme production.

\begin{tabular}{|c|c|c|c|}
\hline Inorganic nitrogen & $\begin{array}{c}\text { Pectinase activity } \\
(\mathbf{u} / \mathbf{g})\end{array}$ & $\begin{array}{c}\text { Proteinase activity } \\
(\mathbf{u} / \mathbf{g})\end{array}$ & $\begin{array}{c}\text { Cellulase activity } \\
(\mathbf{u} / \mathbf{g})\end{array}$ \\
\hline Control & $16288 \pm 594^{\mathrm{a}}$ & $3001 \pm 79^{\mathrm{a}}$ & $1025 \pm 31^{\mathrm{a}}$ \\
\hline $\mathrm{NH}_{4} \mathrm{NO}_{3}$ & $17528 \pm 532^{\mathrm{bc}}$ & $3238 \pm 86^{\mathrm{bc}}$ & $1045 \pm 35^{\mathrm{ab}}$ \\
\hline$\left(\mathrm{NH}_{4}\right)_{2} \mathrm{SO}_{4}$ & $18048 \pm 511^{\mathrm{c}}$ & $3354 \pm 115^{\mathrm{c}}$ & $1103 \pm 30^{\mathrm{c}}$ \\
\hline $\mathrm{NaNO}_{3}$ & $17008 \pm 445^{\mathrm{ab}}$ & $3123 \pm 107^{\mathrm{ab}}$ & $1039 \pm 22^{\mathrm{a}}$ \\
\hline $\mathrm{NH}_{4} \mathrm{Cl}$ & $17344 \pm 308^{\mathrm{bc}}$ & $3077 \pm 98^{\mathrm{ab}}$ & $1098 \pm 36^{\mathrm{bc}}$ \\
\hline
\end{tabular}

Each value represents the mean \pm standard error; with no common superscript letter in a column for a group of substrates are significantly different at $p<0.05$. 
Table 5. Range and variance analyses of pectinase, proteinase and cellulase in orthogonal experiment.

\begin{tabular}{|c|c|c|c|c|c|c|c|c|c|c|}
\hline \multirow{2}{*}{$\begin{array}{c}\text { Medium } \\
1\end{array}$} & \multirow{2}{*}{$\begin{array}{l}A \\
1\end{array}$} & \multirow{2}{*}{$\begin{array}{l}\text { B } \\
1\end{array}$} & \multirow{2}{*}{$\begin{array}{l}\text { C } \\
1\end{array}$} & \multirow{2}{*}{$\begin{array}{l}\text { D } \\
1\end{array}$} & \multicolumn{2}{|c|}{ Pectinase activity (U/g) } & \multicolumn{2}{|c|}{ Proteinase activity (U/g) } & \multicolumn{2}{|c|}{ Cellulase activity (U/g) } \\
\hline & & & & & $14497 \pm 651$ & $11713 \pm 533$ & $2533 \pm 112$ & $3022 \pm 104$ & $935 \pm 37$ & $938 \pm 31$ \\
\hline 2 & 1 & 2 & 2 & 2 & $14155 \pm 548$ & $16006 \pm 746$ & $3138 \pm 143$ & $3143 \pm 110$ & $1139 \pm 46$ & $1082 \pm 43$ \\
\hline 3 & 1 & 3 & 3 & 3 & $13145 \pm 602$ & $12510 \pm 554$ & $2614 \pm 112$ & $2925 \pm 98$ & $919 \pm 41$ & $939 \pm 40$ \\
\hline 4 & 2 & 1 & 2 & 3 & $14288 \pm 673$ & $15898 \pm 635$ & $2819 \pm 138$ & $2872 \pm 79$ & $1019 \pm 45$ & $1058 \pm 38$ \\
\hline 5 & 2 & 2 & 3 & 1 & $21168 \pm 823$ & $20672 \pm 594$ & $3585 \pm 154$ & $3761 \pm 123$ & $1179 \pm 42$ & $1208 \pm 51$ \\
\hline 6 & 2 & 3 & 1 & 2 & $20136 \pm 877$ & $19916 \pm 601$ & $3119 \pm 162$ & $3429 \pm 117$ & $1074 \pm 39$ & $1163 \pm 44$ \\
\hline 7 & 3 & 1 & 3 & 2 & $15341 \pm 647$ & $14754 \pm 544$ & $2334 \pm 98$ & $2316 \pm 89$ & $1031 \pm 48$ & $1088 \pm 46$ \\
\hline 8 & 3 & 2 & 1 & 3 & $18230 \pm 488$ & $17742 \pm 823$ & $2507 \pm 107$ & $2719 \pm 78$ & $1039 \pm 41$ & $1106 \pm 40$ \\
\hline 9 & 3 & 3 & 2 & 1 & $13938 \pm 614$ & $16500 \pm 704$ & $3395 \pm 99$ & $3238 \pm 106$ & $1070 \pm 33$ & $1037 \pm 42$ \\
\hline \multicolumn{11}{|c|}{ Pectinase } \\
\hline $\mathrm{K}_{1}$ & 13671 & 14415 & 17039 & 16414 & & & & & & \\
\hline $\mathrm{K}_{2}$ & 18680 & 17995 & 15130 & 16718 & & & & & & \\
\hline $\mathrm{K}_{3}$ & 16084 & 16024 & 16265 & 15302 & & & & & & \\
\hline $\mathrm{R}$ & 5009 & 3580 & 1909 & 1416 & & & & & & \\
\hline $\mathrm{F}$ & $31.3^{\star \star}$ & $16.1^{\star \star}$ & $4.6^{*}$ & 2.8 & & & & & & \\
\hline \multicolumn{11}{|c|}{ Proteinase } \\
\hline $\mathrm{K}_{1}$ & 2896 & 2649 & 2888 & 3256 & & & & & & \\
\hline $\mathrm{K}_{2}$ & 3264 & 3142 & 3100 & 2913 & & & & & & \\
\hline $\mathrm{K}_{3}$ & 2751 & 3120 & 2923 & 2742 & & & & & & \\
\hline $\mathrm{R}$ & 513 & 493 & 212 & 514 & & & & & & \\
\hline $\mathrm{F}$ & $14.0^{* \star}$ & $15.6^{\star \star}$ & 2.6 & $13.7^{\star *}$ & & & & & & \\
\hline \multicolumn{11}{|c|}{ Cellulase } \\
\hline $\mathrm{K}_{1}$ & 992 & 1012 & 1043 & 1061 & & & & & & \\
\hline $\mathrm{K}_{2}$ & 1117 & 1126 & 1068 & 1096 & & & & & & \\
\hline $\mathrm{K}_{3}$ & 1062 & 1034 & 1061 & 1013 & & & & & & \\
\hline $\mathrm{R}$ & 125 & 114 & 25 & 83 & & & & & & \\
\hline $\mathrm{F}$ & $18.6^{\star \star}$ & $17.3^{\star \star}$ & 0.8 & $8.2^{*}$ & & & & & & \\
\hline
\end{tabular}

$\mathrm{H}_{2} \mathrm{O}(\%, \mathrm{w} / \mathrm{w})$; B: load (g, dry weight); C: $\left(\mathrm{NH}_{4}\right)_{2} \mathrm{SO}_{4}(\%, w / w) ; \mathrm{D}: \mathrm{KH}_{2} \mathrm{PO}_{4}(\%, w / w)$. Each value represents the mean \pm standard error; ${ }^{* *} \mathrm{~F}>\mathrm{F}_{0} 01,{ }^{*} \mathrm{~F}>\mathrm{F}_{0} 0$ 
Table 6. Effects of inoculum level, temperature and initial pH on the enzyme production.

\begin{tabular}{|c|c|c|c|}
\hline $\begin{array}{c}\text { Inoculum level } \\
(\%, w / w)\end{array}$ & $\begin{array}{c}\text { Pectinase activity } \\
\text { (u/g) }\end{array}$ & $\begin{array}{c}\text { Proteinase activity } \\
\text { (u/g) }\end{array}$ & $\begin{array}{c}\text { Cellulase activity } \\
(\mathrm{u} / \mathrm{g})\end{array}$ \\
\hline 0.2 & $14004 \pm 250^{a}$ & $3033 \pm 83^{a}$ & $733 \pm 15^{a}$ \\
\hline 0.3 & $15265 \pm 362^{b}$ & $3393 \pm 87^{b}$ & $982 \pm 29^{b}$ \\
\hline 0.4 & $18548 \pm 566^{c}$ & $3629 \pm 111^{c}$ & $1151 \pm 45^{c}$ \\
\hline 0.5 & $18028 \pm 446^{\mathrm{cd}}$ & $3345 \pm 88^{b}$ & $1100 \pm 39^{c}$ \\
\hline 0.6 & $16081 \pm 410^{d}$ & $3240 \pm 74^{b}$ & $1023 \pm 34^{b}$ \\
\hline \multicolumn{4}{|c|}{ Temperature $\left({ }^{\circ} \mathrm{C}\right)$} \\
\hline 21 & $9506 \pm 219^{a}$ & $1890 \pm 52^{a}$ & $405 \pm 12^{a}$ \\
\hline 24 & $10585 \pm 344^{b}$ & $2093 \pm 65^{b}$ & $473 \pm 12^{b}$ \\
\hline 27 & $17284 \pm 485^{c}$ & $3376 \pm 100^{c}$ & $900 \pm 21^{c}$ \\
\hline 30 & $18603 \pm 623^{d}$ & $3274 \pm 125^{c}$ & $1154 \pm 38^{d}$ \\
\hline 33 & $18249 \pm 574^{d}$ & $2869 \pm 82^{d}$ & $934 \pm 38^{c}$ \\
\hline \multicolumn{4}{|c|}{$\mathrm{pH}$} \\
\hline 3 & $10958 \pm 257^{a}$ & $1594 \pm 23^{a}$ & $632 \pm 12^{a}$ \\
\hline 4 & $18598 \pm 649^{b}$ & $3457 \pm 98^{b}$ & $1091 \pm 29^{b}$ \\
\hline 5 & $16283 \pm 544^{c}$ & $3674 \pm 134^{c}$ & $1207 \pm 41^{c}$ \\
\hline 6 & $15298 \pm 457^{d}$ & $3527 \pm 110^{b c}$ & $1065 \pm 36^{b}$ \\
\hline 7 & $14127 \pm 428^{\mathrm{e}}$ & $2645 \pm 84^{d}$ & $905 \pm 29^{d}$ \\
\hline
\end{tabular}

Each value represents the mean \pm standard error; with no common superscript letter in a column for a group of treatments are significantly different at $p<0.05$. 
Table 7. Effect of fermentation on the nutrition of substrate.

\begin{tabular}{|c|c|c|}
\hline $\begin{array}{l}\text { Nutrition } \\
\text { component }\end{array}$ & $\begin{array}{l}\text { Control } \\
(g / 100 g)\end{array}$ & Fermented substrate $(\mathrm{g} / 100 \mathrm{~g})$ \\
\hline Crude protein & $23.52 \pm 0.67$ & $33.12 \pm 0.71$ \\
\hline Pure protein & $20.03 \pm 0.42$ & $26.99 \pm 0.63$ \\
\hline Asp & $1.98 \pm 0.03$ & $2.96 \pm 0.03$ \\
\hline Thr & $0.76 \pm 0.02$ & $1.51 \pm 0.02$ \\
\hline Ser & $1.02 \pm 0.03$ & $1.71 \pm 0.02$ \\
\hline Glu & $4.98 \pm 0.17$ & $5.06 \pm 0.14$ \\
\hline Gly & $0.97 \pm 0.02$ & $1.63 \pm 0.02$ \\
\hline Ala & $0.73 \pm 0.02$ & $1.25 \pm 0.03$ \\
\hline Cys & $0.61 \pm 0.01$ & $0.56 \pm 0.01$ \\
\hline Val & $1.01 \pm 0.03$ & $1.62 \pm 0.02$ \\
\hline Met & $0.55 \pm 0.01$ & $1.01 \pm 0.02$ \\
\hline Ile & $0.67 \pm 0.01$ & $1.21 \pm 0.02$ \\
\hline Leu & $1.22 \pm 0.02$ & $2.17 \pm 0.03$ \\
\hline Tyr & $0.27 \pm 0.01$ & $0.67 \pm 0.01$ \\
\hline Phe & $0.58 \pm 0.01$ & $0.94 \pm 0.01$ \\
\hline Lys & $1.15 \pm 0.02$ & $1.74 \pm 0.02$ \\
\hline His & $0.35 \pm 0.01$ & $0.54 \pm 0.01$ \\
\hline Arg & $1.15 \pm 0.03$ & $1.07 \pm 0.02$ \\
\hline Pro & $0.24 \pm 0.01$ & $1.13 \pm 0.02$ \\
\hline Total amino acid & 18.24 & 26.78 \\
\hline
\end{tabular}

The unfermented substrate was adopted as the control. All measurements were carried out in triplicate. Each value represents the mean \pm standard error. 